\title{
The main factors of the origin and morphology evolution of underwater canyons in the Southern and Middle basins of the Baikal depression
}

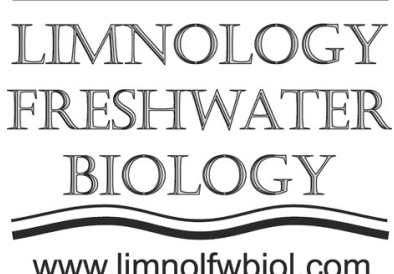

www.limnolfwbiol.com

\author{
Kononov E.E. ${ }^{1,2 *}$, Khlystov O.M. ${ }^{1}$ \\ ${ }^{1}$ Limnological Institute, SB RAS, Ulan-Batorskaya Street 3, Irkutsk, 664033, Russia \\ ${ }^{2}$ V.B. Sochava Institute of Geography SB RAS, Ulan-Batorskaya Street 1, Irkutsk, 664033, Russia
}

\begin{abstract}
We present the results of morphological analysis of the bottom topography in the Southern and Middle basins of Lake Baikal based on the high-precision bathymetric survey. There is a dominant influence of the fault tectonics at the origin of underwater canyons. Turbidity currents play a great role in the further evolution of the underwater valley. They intensify during abrupt seismic shocks or storm injections into the canyon heads. In cases when canyon heads are close to the river estuaries, terrestrial rivers have a significant impact on the speed of the formation of the canyon valleys. The topography of the original surface often determines the morphological features of the valleys. Climate change in the Pleistocene and fluctuations in the water level of the lake also could initiate the formation of some canyons in Lake Baikal.

The studies have indicated the high morphological and genetic similarity of Baikal canyons with marine ones.
\end{abstract}

Keywords: Lake Baikal, morphology of canyons, tectonics, levels

\section{Introduction}

E.B. Karabanov and V.A. Fialkov first described the study history of underwater canyons in Lake Baikal until the mid-1990s (Karabanov and Fialkov, 1987). Only surveying the bottom with multi-beam echosounders yielded more detailed data on canyons (Khlystov et al., 2018; Kononov et al., 2019a; 2019b). Here, we study the factors that determine morphological features of the Baikal valleys with canyons and compare them with the morphology of the marine canyon valleys.

\section{Methods and materials}

The study of the Baikal bottom topography was carried out using the ELACSeaBeam 1050 and KonengsbergEM710S multi-beam echosounders that ensured bathymetric data with detail at least four times exceeding the materials of the INTAS bathymetric map (De Batist et al., 2016).

\section{Results}

The pattern of the canyon valleys in the Southern and Middle basins is extremely diverse: from predominantly rectilinear to highly sinuous. The profiles of the valleys range from V-shaped to trapezoidal. The depths of their incision vary from several meters to $300-350 \mathrm{~m}$, and the width of the valley bottoms - from $200 \mathrm{~m}$ to $2.0 \mathrm{~km}$. Spatially, the canyon valleys are developed either directly from the coastline or at a distance of hundreds of meters to several kilometres. The upper parts of many valleys are located near the 40-m isobath. Estuarine parts of the valleys are, as a rule, widened, and fans are sparsely developed. The average slope of the canyon thalwegs is ca. $4 \cdot 1^{\circ}$, and the average length of the canyons is 23.5 $\mathrm{km}$. Canyons developed along the western side of the lake have slopes of the valley thalwegs of up to $40^{\circ}-45^{\circ}$, stepped longitudinal profile, sub-vertical sides of the valleys, and a small length.

\section{Discussion}

Most transformations of the bottom surface and many features of its topography are largely caused by tectonic processes. A network of faults determines the pattern of the valley network for many Baikal canyons. A sinuous and fractured nature of the valley in the Kukuy canyon, abrupt change in the orientation of the Boyarsk and Slyudyanka canyon valleys as well as rectilinear nature of the Kharauz canyon valley are completely due to the presence of tectonic structures and faults. The high seismicity of the depression contributes to the formation 


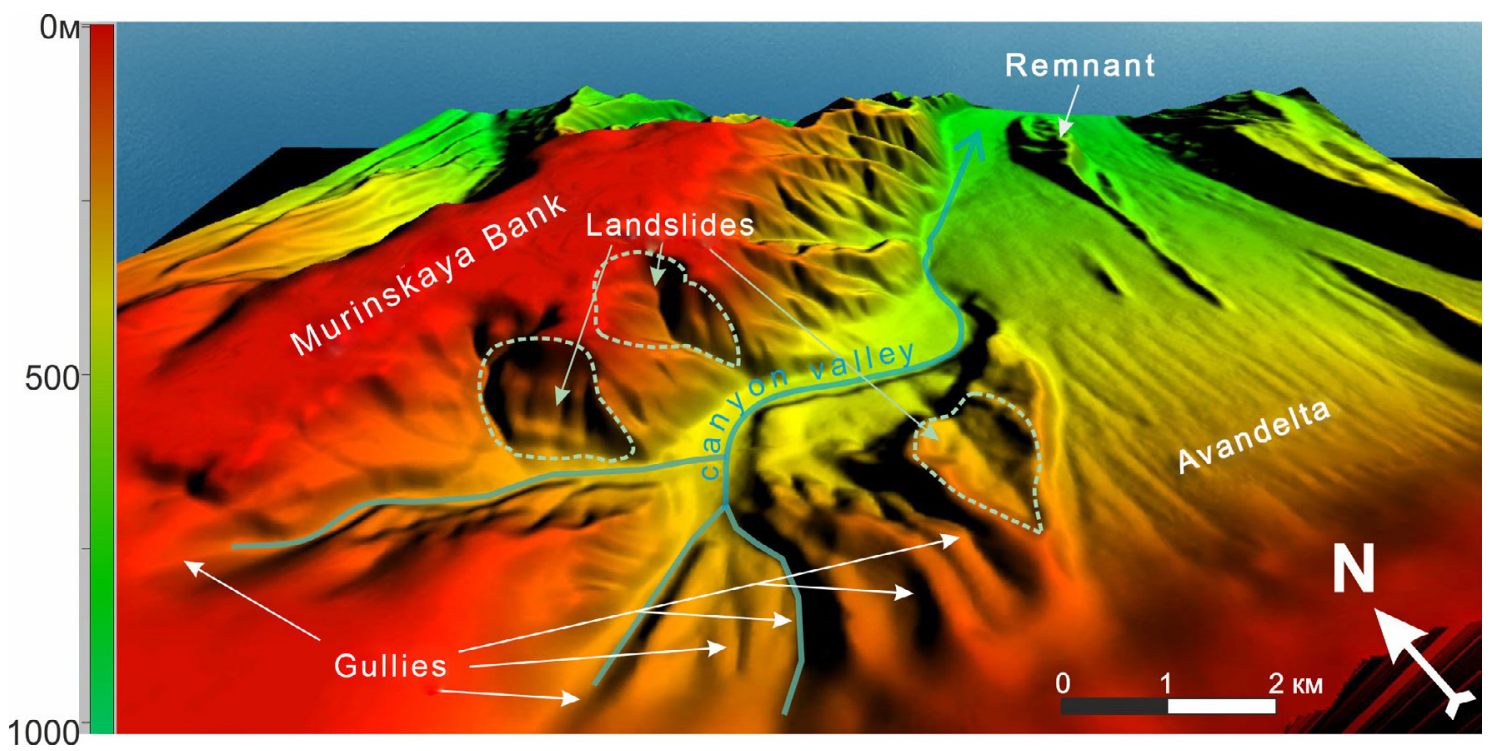

Fig. 1. Landslides and ravines in the upper part of the valley of the Murino canyon

of critical loose masses and their displacement down along the underwater slope. Based on the results of the studies conducted near the Kukuy canyon, N. Le Dantec (Le Dantec et al., 2016) concluded that earthquakes are a trigger for the destruction of the slope and formation of sediments. In the valleys of many Baikal canyons, in the upper parts and on the sides, there were traces of collapses, landslides and dislocations, whose formation earthquakes undoubtedly provoked.

Studies have revealed that the nature of the original surface determines many morphological features of Baikal canyons as well as marine ones (Harris and Whiteway, 2011). Along the east and south coasts, where the slope surface is gentle and extends deep down the basin from the coastline for 15-30 $\mathrm{km}$ as well as consists of loose Cainozoic strata, the canyon valleys are extended (up to $45 \mathrm{~km}$ ), wide and deeply cut into the slope surface (Khlystov et al., 2018; Kononov et al., 2019a). Lithological features of the rocks along the west coast are an unfavourable factor for the formation of canyons. Here, the canyon valleys are morphologically inexpressive and represent deep and very narrow hollow crevices.

The assumptions (Urabe et al., 2004; Khlystov et al., 2008) that at the MIS 2 stage the water level in the lake was by $40-45 \mathrm{~m}$ lower than now allow us to conclude that the channels of rivers or breaking wave activity at that time could have influenced the origin and development of these canyons.

The morphological appearance of the underwater erosional forms in Lake Baikal is in many respects similar to marine ones. The average slope of the Baikal canyon thalwegs is comparable with the slopes of marine canyons $\left(3.8^{0}-5.2^{\circ}\right.$ ). The average length of Baikal canyons $(23.5 \mathrm{~km})$ is shorter than that of marine ones (43.4 km) (Harris and Whiteway, 2011), which is owing to the smaller parameters of the lake shelf and continental slope, on which underwater valleys can develop. In the plan, the pattern of the valleys of Baikal canyons is rather diverse and often similar to marine canyon valleys. The upper parts of some canyons are sinuous and sometimes complicated by ravines; the upper parts of other canyons are rectilinear. Middle parts of the valleys are generally sinuous. The lower parts can be also sinuous or rectilinear.

Illustrative material of marine canyons (Micallef et al., 2014; De Almeida et al., 2015) indicates the same ambiguity in the nature of their pattern in the plan.

\section{Conclusion}

Tectonics plays a huge role in the formation and evolution of Baikal canyons. On the one hand, tectonic movements and earthquakes catalyze the formation of a canyon, as well as of gravity flows, and, on the other hand, they transform the valleys of already existing canyons, changing their appearance. The topography of the original surface and lithological features of the strata play an important role in the formation of canyons and their evolution.

Terrestrial rivers directly influence the evolution of canyons in cases when their valleys reach the coastline.

The studies of underwater canyons in the Southern and Middle basins of Lake Baikal have indicated their large morphological and genetic similarity with marine canyons. This similarity allows us to use the materials on marine continental margins for assessing the processes that take place in canyons of Lake Baikal.

\section{Acknowledgements}

This study was supported by the LIN SB RAS State Task No 0345-2019-0007. 


\section{References}

De Almeida N., Vital H., Gomes M. 2015. Morphology of submarine canyons along the continental margin of the Potiguar Basin, NE Brazil. Marine and Petroleum Geology 68: 307-324.

De Batist M., Canals M., Sherstyankin P., Alekseev S. 2016. A new bathymetric map of Lake Baikal. Sc 1:200 000 . URL: http://www.lin.irk.ru /insta/index.html (accessed on 27 July)

Harris P.T., Whiteway T. 2011. Global distribution of large submarine canyons: Geomorfic differences between active and passive continental margins. Marine Geology 285: 69-86.

Karabanov E.B., Fialkov V.A. 1987. Podvodnyie kanyony Baykala [Underwater canyons of Lake Baikal]. Novosibirsk: Nauka SO RAN.

Khlystov O.M., Khanaev I.V., Grachev M.A. 2008. Evidence of lowstand of Lake Baikal during the Last Glaciation. Doklady Earth Sciences 422: 1133-1136.

Khlystov O.M., Kononov E.E., Minami H. et al. 2018. New evidence on the relief of the southern underwater slope in the South Baikal basin. Geography and Natural Resources 1: 33-38.
Kononov E.E., Khlystov O.M., Minami H. et al. 2019a. Canyons of the eastern shore of Southern Baikal: morphology and genesis. Geography and Natural Resources 1: 37-45.

Kononov E.E., Khlystov O.M., Kazakov A.V. et al. 2019b. The lake floor morphology of the Southern Baikal rift basin as a result of holocene and Late Pleistocene seismogenic and gravitational processes. Quaternary International 524: 115-121.

Le Dantec N., Babonneau N., Franzetti M. et al. 2016. Morphological analysis of the upper reaches of the Kukuy Canyon derived from shallow bathymetry. In: Karthe D., Chalov S., Kasimov N., Kappas M. (Eds.) Water and Environment in the Selenga-Baikal Basin. Edition: International Research Cooperation for an Ecoregion of Global Relevance, Chapter: 3, Publisher: Ibidem, pp. 179-190.

Micallef A., Ribó M., Canals M. et al. 2014. Space-for-time substitution and the evolution of a submarine canyon-channel system in a passive progradationalmargin. Geomorphology 221: $34-50$.

Urabe A., Tateishi M., Inouchi M.Y. et al. 2004. Lakelevel changes during the past 100,000 years at Lake Baikal, Southern Siberia. Quaternary research 62(2): 214-222. 